\title{
AKIBAT HUKUM DENGAN ADANYA KEWENANGAN DESA BERDASARKAN UNDANG-UNDANG NOMOR 6 TAHUN 2014 TENTANG DESA DALAM PERBUATAN PUBLIK
}

Joejoen Tjahjani, SH, M.H

joejoen668@gmail.com

Fakultas Hukum Universitas Islam Lamongan

\begin{abstract}
ABSTRAK
Kelahiran Undang-undang Nomor 6 tahun 2014 tentang Desa diharapkan mampu untuk mengakomodir kepentingan dan kebutuhan masyarakat Desa. Pemerintahan Desa dijalankan oleh Kepala Desa dan Badan Permusyawaratan Desa. Kepala Desa bertugas menyelenggarakan Pemerintahan Desa, melaksanakan Pembangunan Desa, pembinaan kemasyarakatan Desa dan pemberdayaan masyarakat Desa sedangkan Badan Permusyawaratan Desa mempunyai fungsi membahas dan menyepakati Rancangan Peraturan Desa bersama Kepala Desa, menampung dan menyalurkan aspirasi masyarakat Desa dan melakukan pengawasan kinerja Kepala Desa. Berdasarkan hasil penelitian dengan berlakunya Undang-undang Nomor 6 tahun 2014, terjadi Perubahan Kedudukan, tugas, fungsi dan wewenang Kepala Desa dan BPD, Kepala Desa tidak lagi bertanggung jawab kepada BPD. Hubungan kerja antara Kepala Desa dengan BPD adalah hubungan kemitraan, konsultasi dan koordinasi yang diatur dalam Undang-Undang Baru Tersebut.
\end{abstract}

Kata Kunci : UU No 6 Tahun 2014 Tentang Desa, Kewenangan BPD, Hubungan kerja kepala desa dengan BPD.

\section{PENDAHULUAN}

Dalam Undang-Undang Nomer 6 Tahun 2014 desa merupakan kesatuan hukum otonom dan memiliki hak dan wewenang untuk mengatur rumah tangga sendiri. Berdasarkan Undang-Undang Nomor 23 Tahun 2014 tentang Pemerintahan Daerah, desa tidak lagi merupakan level administrasi dan menjadi bawahan daerah, melainkan menjadi independent community, yang masyarakatnya berhak berbicara atas kepentingan sendiri dan bukan ditentukan dari atas ke bawah. Undang Undang Nomor
6 Tahun 2014 tentang desa disahkan dalam Sidang Paripurna Dewan Perwakilan Rakyat Republik Indonesia (DPR-RI), tanggal 18 Desember 2013, setelah menempuh perjalanan panjang selama tujuh tahun (2007-2013). Seluruh komponen bangsa menyambutnya sebagai kemenangan besar. Sebab Undang-Undang Nomor 6 Tahun 2014 tentang desa menjadi bukti ketegasan komitmen Pemerintah Indonesia dan anggota DPR-RI untuk melindungi dan memberdayakan desa agar menjadi lebih kuat, mandiri, dan demokratis. sehingga dapat menciptakan landasan yang kokoh dalam melaksanakan 
pemerintahan dan pembangunan menuju masyarakat yang adil, makmur dan sejahtera.

Ketika diberlakukannya UndangUndang Nomor 6 Tahun 2014 Tentang Desa di Indonesia, berbagai pihak telah banyak memberikan apresiasi kepada pemerintah pusat terhadap perkembangan otonomi desa yang sebelumnya. Sekaligus dengan Undang-Undang Nomor 6 Tahun 2014 ini nantinya desa-desa di Indonesia mempunyai masa depan yang lebih baik pengaturannya dari pada Undang-Undang sebelumnya yaitu Undang-Undang Nomor 5 Tahun 1999 Tentang Desa, UndangUndang Nomor 22 Tahun 1999 Tentang pemerintahan daerah dan Undang-Undang Nomor 32 Tahun 2004 Tentang pemerintahan daerah termasuk di dalamnya mengatur tentang desa-desa di Indonesia ${ }^{1}$.

Dengan ditetapkannya UndangUndang Desa Nomor 6 Tahun 2014, kedudukan Badan Permusyawaratn Desa mengalami perubahan. Jika sebelumnya Badan Permusyawaratn Desa merupakan unsur penyelenggara pemerintahan maka sekarang menjadi lembaga desa. Kini fungsi Badan Permusyawaratn Desa yaitu menyalurkan aspirasi, merencanakan Anggaran Pendapatan dan Belanja Desa

1 Diantha, Pasek. 2014. Analisis Yuridis Penerapan Undang-undang Nomor 6 Tahun 2014
(APBDes), dan mengawasi pemerintahan desa.

$\begin{array}{ccc}\text { Sedangkan } & \text { tugasnya adalah } \\ \text { menyelenggarakan } & \text { musyawarah desa }\end{array}$
dengan peserta terdiri kepala desa, perangkat desa kelompok, dan tokoh masyarakat. Jumlah pesertanya tergantung situasi kondisi setiap desa. Musyawarah desa berfungsi sebagai ajang kebersamaan dan membicarakan segala kebijakan tentang desa. Dalam hal ini, Badan Permusyawaratn Desa diharapkan menjadi wadah atau gelanggang politik baru bagi warga desa dan membangun tradisi demokrasi, sekaligus tempat pembuatan kebijakan publik desa serta menjadi alat kontrol bagi proses penyelenggaraan pemerintahan dan pembangunan ditingkat desa.

Hal ini bisa terealisasi apabila Badan Permusyawaratn Desa sebagai mitra kepala desa, berperan aktif dalam membangun desa bersama kepala desa dan masyarakat. Undang-Undang Desa lahir dari perjuangan dan perjalanan yang panjang untuk mencapai Inti dari Undang-Undang ini adalah mengenai alokasi dana untuk Desa.

Pembatasan masalah dalam suatu penelitian ini dimaksudkan agar permasalahan yang dibahas lebih fokus, serta untuk mempermudah penulis dalam dari denpasarkota.go.id 
memecahkan permasalahan yang akan diteliti. Sehingga tujuan dan sasaran bisa dicapai dengan jelas serta mendapatkan hasil yang diharapkan pengaturan kewenangan desa dalam Undang-undang Nomor 6 Tahun 2014 tentang Desa.

Berdasarkan pada uraian yang mendasari penelitian ini di atas, maka peneliti merumuskan masalah yang akan dibahas dalam penelitian ini adalah Apakah akibat hukum dengan adanya kewenangan desa berdasarkan Undang-Undang Nomor 6 Tahun 2014 tentang Desa?

\section{METODE PENELITIAN}

Dalam melakukan penelitian ini dibutuhkan bahan yang berupa data informasi yang berkaitan tentang subyek penelitian secara langsung maupun tidak langsung, metode penelitian meliputi:

Tipe penelitian hukum yang dilakukan adalah yuridis normatif (hukum normatif). Metode penelitian hukum normatif adalah suatu prosedur penelitian ilmiah untuk menemukan kebenaran berdasarkan logika keilmuan hukum dari sisi normatifnya. ${ }^{2}$ Oleh karena itu penelitian hukum ini difokuskan untuk mengkaji penelitian hukum tentang kaidahkaidah atau norma-norma dalam hukum positif, yakni norma hukum yang terkait dengan kewenangan Badan Permusyawaratan Desa (BPD) menurut Undang-Undang Nomor 6 Tahun 2014 Tentang Desa.

Tipe penelitian yang digunakan adalah tipe penelitian yuridis normatif, maka pendekatan yang digunakan adalah pendekatan perundang-undangan (statute approach). Pendekatan tersebut melakukan pengkajian peraturan perundang-undangan yang berhubungan dengan pokok permasalahan. Selain itu juga digunakan pendekatan konsep (Conceptual approach). Pendekatan konsep ini digunakan dalam rangka untuk melihat konsep-konsep yang terkait dengan hubungan antara Badan Permusyawaratan Desa dengan Kepala Desa dalam penyelenggaraan pemerintahan desa.

Bahan hukum yang dipergunakan dalam penelitian ini adalah sebagai berikut

a. Bahan hukum primer: bahan hukum primer merupakan bahan hukum yang bersifat autoritatif artinya mempunyai otoritas bahan hukum terdiri dari perundang-undangan, catatan resmi, atau risalah dalam pembuatan perundang-undangan dan

2 Johnny Ibrahim, Teori \& Metode Penelitian Hukum Normatif, Banyumedia Publishing, Malang 2006, h..57 
putusan hakim. Adapun bahan hukum primer antara lain: Undang Undang Dasar 1945,

b. Bahan sekunder, yaitu bahan yang diperoleh dari buku teks, jurnal-jurnal, pendapat para sarjana dan kasus-kasus hukum. ${ }^{3}$

Baik bahan primer maupun bahan sekunder dikumpulkan berdasar-kan topik permasalahan yang telah dirumuskan dan diklasifikasi menurut sumber dan hirarkinya untuk dikaji secara komprenensif.

Adapun bahan yang diperoleh dalam penelitian studi kepustakaan, aturan perundang-undangan, yang penulis uraikan dan dihubungkan sedemikian rupa, sehingga disajikan dalam penulisan yang lebih sistematis guna menjawab perumusan masalah yang dirumuskan.Cara pengolahan bahan dilakukan secara deduktif yakni menarik kesimpulan dari suatu permasalahan yang bersifat umum terhadap permasalahan kongkrit yang dihadapi.

\section{HASIL DAN PEMBAHASAN}

Sebelumnya pengaturan tentang Badan Permusyawaratan Desa diatur di dalam Undang-undang No 23 Tahun 2014 tentang Pemerintahan Daerah. Sebagai tindak lanjut dari dikeluarkannya Undangundang Nomor 23 tahun 2014 selanjutnya pemerintah Daerah mengeluarkan Peraturan Daerah Nomor 13 Tahun 2006 Tentang Pembentukan Badan Permusyawaratan Desa. Dalam Perda Nomor 13 Tahun 2006 pengertian Badan Permusyawaratan Desa terdapat di dalam ketentuan umum pasal 1 angka 6 yang bunyinya:" Badan Permusyawaratan Desa yang selanjutnya disebut BPD adalah lembaga yang merupakan perwujudan demokrasi dalam penyelenggaraan pemerintahan Desa sebagai unsur penyelenggara pemerintahan Desa".

Wewenang dan fungsi Badan Permusyawaratan Desa di dalam Perda Nomor 13 Tahun 2006 Tentang Pembentukan Badan Permusyawaratan Desa diatur di dalam Pasal 11 dan Pasal 12 Wewenang Badan Permusyawaratan Desa diatur didalam Pasal 11 Ayat (1) yang bunyinya: Badan Permusyawaratan Desa Mempunyai Wewenang ;

1. Membahas rancangan Peraturan Desa bersama Perbekel.

2. Melaksanakan pengawasan terhadap pelaksanaan Peraturan Desa dan Peraturan Perbekel.

3. Mengusulkan pengangkatan dan pemberhentian Perbekel.

4. Membentuk panitia pemilihan Perbekel.

${ }^{3}$ Peter Mahmud Marzuki. Penelitian Hukum. Universitas Airlangga. Surabaya. h. 15. 
5. Menggali, menampung, menghimpun, merumuskan dan menyalurkan aspirasi masyarakat

6. Menyusun tata tertib Badan Permusyawaratan Desa.

Badan Permusyawaratan Desa merupakan Badan Permusyawaratan di tingkat Desa yang turut membahas dan menyepakati berbagai kebijakan dalam penyelenggaraan pemerintahan Desa. Dalam upaya meningkatkan kinerja kepala pemerintahan Desa dan memfasilitasi penyelenggaraan musyawarah Desa bersama Perangkat Desa.

Musyawarah Desa adalah forum musyawarah antara Badan Permusyawaratan Desa, Pemerintah Desa, dan unsur masyarakat yang diselenggarakan oleh Badan Permusyawaratan Desa untuk menyepakati hak yang bersifat strategis dalam penyelenggaraan Pemerintahan Desa. Musyawarah Desa merupakan forum dari pemangku kepentingan di Desa termasuk masyarakatnya. Hasil dari musyawarah Desa yang berbentuk kesepakatan yang dituangkan di dalam keputusan hasil musyawarah dijadikan dasar oleh Badan Permusyawaratan Desa dan pemerintah Desa dalam menetapkan kebijakan yang meliputi: penataan Desa, perencanaan Desa, kerja sama Desa, rencana investasi yang masuk ke Desa, pembentukan badan usaha milik Desa, penambahan dan pelepasan aset desa serta kejadian luar biasa ${ }^{4}$.

Undang-undang Nomor 6 tahun 2014

tentang Desa dalam ketentuan umumnya memberikan penjelasan tentang Desa sebagai berikut, Desa adalah kesatuan masyarakat hukum yang memiliki batas wilayah yang berwenang untuk mengatur dan mengurus urusan Pemerintahan, kepentingan masyarakat setempat berdasarkan prakarsa masyarakat, hak asal usul, dan/atau hak tradisional yang diakui dan dihormati dalam sistem Pemerintahan Negara Kesatuan Republik Indonesia.

Kata mengatur memiliki arti kewenangan dalam membuat kebijakan yang bersipat mengatur (policy regulatioan) sedangka kata mengurus memiliki arti kewenangan membuat aturan pelaksanaan (policy implementation). Kesatuan masyarakat hukum yang memiliki kewenangan mengatur dan mengurus kepentingannya sendiri berarti kesatuan masyarakat hukum tersebut

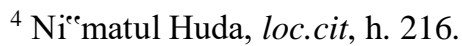


mempunyai otonomi karena ia berwenang membuat kebijakan yang bersipat mengatur sekaligus membuat aturan pelaksanaannya. Dengan demikian Desa memiliki otonomi untuk mengatur dan mengurus kewenangan berdasarkan hak asal usul dan kewenangan lokal berskala Desa. Penyelenggaraan pemerintahan Desa memasuki babak baru dengan kewenangan pengaturan ada pada Pemerintahan Desa itu sendiri yang berasal dari asal usul dan adat istiadat yang dikembangkan, dipelihara dan dipertahankan masyarakat setempat dari dulu sampai sekarang. Hal ini berarti urusan yang secara adat telah diatur dan diurus diakui oleh undang-undang dalam sistem Pemerintahan Negara Kesatuan Republik Indonesia. Dalam melaksanakan pembangunan Desa Peran serta masyarakat mutlak diperlukan dalam rangka kebersamaan, kekeluargaan, dan kegotongroyongan guna mewujudkan perdamaian dan keadilan sosial bagi masyarakat Desa.
Berdasarkan kriteria kewenangan sebagaimana yang dijelaskan diatas, maka kewenangan lokal berskala Desa meliputi bidang Pemerintahan Desa, bidang Pembangunan Desa, bidang Kemasyarakatan Desa dan bidang Pemberdayaan masyarakat Desa Untuk mempermudah memahami bagaimana pengaturan hubungan kerja antara Kepala Desa dengan Badan Permusyawaratan Desa menurut Undang-undang Nomor 6 tahun 2014 tentang Desa dapat dijelaskan pengaturannya sebagai berikut:

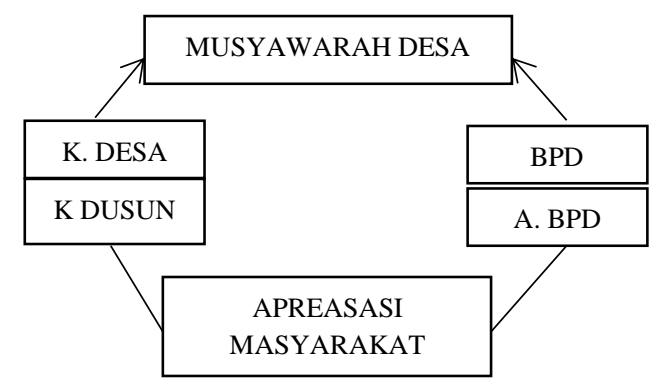

Gambar Diagram Pola Relasi Kerja Kepala Desa dengan BPD dalam Aspirasi Masyarakat

Keterangan :

Berdasarkan skema diatas aspirasi masyarakat dapat diajukan melalui Kepala Dusun atau Anggota Badan Permusyawaratan Desa, jika aspirasi 
disampaikan melalui Kepala Dusun, maka akan disampaikan ke Kepala Desa kemudian disampaikan kepada Badan Permusyawaratn Desa untuk dibahas dan diputuskan bersama untuk dilaksanakan, selanjutnya jika aspirasi tersebut disampaikan lewat anggota Badan Permusyawaratn Desa, diteruskan kepada Ketua BPD kemudian dirapatkan dalam musyawarah Badan Permusyawaratn Desa hasil musyawarah tersebut selanjutnya disampaikan kepada Kepala Desa untuk ditindaklanjuti.

\section{PENUTUP}

Kesimpulan yang dapat ditarik dari hasil penelitian tentang Kewenanagan Badan Permusyawaratan Desa (BPD) menurut Undang-undang Nomor 6 tahun 2014 tentang Desa adalah sebagai berikut : Wewenang Badan Permusyawaratan Desa adalah Membahas rancangan Peraturan Desa bersama Perbekel, Melaksanakan pengawasan terhadap pelaksanaan Peraturan Desa dan Peraturan Perbekel, Mengusulkan pengangkatan dan pemberhentian Perbekel, Membentuk panitia pemilihan Perbekel, Menggali, menampung, menghimpun, merumuskan dan menyalurkan aspirasi masyarakat, Menyusun tata tertib Badan Permusyawaratan Desa. Dan Badan Permusyawaratan Desa merupakan Badan Permusyawaratan di tingkat Desa yang turut membahas dan menyepakati berbagai kebijakan dalam penyelenggaraan pemerintahan Desa. Dalam upaya meningkatkan kinerja kepala pemerintahan Desa dan memfasilitasi penyelenggaraan musyawarah Desa bersama Perangkat Desa.

Saran dan masukan penulisan adalah sebagai berikut :

1. Struktur Pemerintahan Desa agar secepatnya di sesuaikan dengan peraturan Perundang-undangan yakni Undang-Undang Nomor 6 tahun 2014 tentang Desa dan Peraturan Pemerintah Nomor 43 tahun 2014 tentang Peraturan Pelaksana Undang-Undang Nomor 6 tahun 2014 tentang Desa, agar 
Pemerintahan Desa dapat berjalan secara

Demokratis, Transparan dan Akuntabel.

\section{DAFTAR PUSTAKA}

Amin Suprihatini, Pemerintahan Desa dan Kelurahan, Cempaka Putih, Klaten, 2007.

Ateng Syafrudin dan Suprin $\mathrm{Na}^{\mathrm{ee}} \mathrm{a}$, Republik Desa (Pergulatan Hukum Tradisional dan Hukum Modern Dalam Desain Otonomi Desa), PT. Alumni, Bandung, 2010.

Daeng Sudirwo, Pokok-Pokok Pemerintahan Di Daerah dan Pemerintahan Desa, Angkasa, Bandung. 1981.

Diantha, Pasek. Analisis Yuridis Penerapan Undang-undang Nomor 6 Tahun 2014 tentang desa. Isu Strategis Triwulan IV. Di download dari denpasarkota.go.id, 2014.

Johnny Ibrahim, Teori \& Metode Penelitian Hukum Normatif, Banyumedia Publishing, Malang 2006.

Peter Mahmud Marzuki. Penelitian Hukum. Universitas Airlangga. Surabaya. 2015. 